\title{
JEFFREY GEIGER
}

\section{Taking Aim: New Documentary and War}

\begin{abstract}
This essay examines some of the contours of new documentary's relationship to war, first characterizing historical and theoretical frameworks while considering the social and spectatorial impact of moving images that have engaged with war themes and imagery. The focus falls on new documentary and representations of the war in Iraq, asking if these cultural mediations of war might indicate shades of an 'Iraq syndrome' in the making. Finally, a close reading of Michael Moore's Fabrenheit 9/11 considers the film in light of social and representational issues facing new documentary, marking the film's postmodernist and surrealist tendencies. I argue that Moore's film ends up projecting ambiguous and perhaps self-contradictory conclusions about the US's reliance on war as a mechanism for advancing its global social, ideological, and economic agendas. At the same time, the film manages to capture elements of the heterogeneity and instability of Americans' own national and patriotic self-perceptions.
\end{abstract}

\section{Introduction}

Most documentaries have one thing in common: each springs from a definite need, each is conceived as an idea-weapon to strike a blow for whatever cause the originator has in mind.

Philip Dunne (qtd. in Barsam 1974, 2)

It may seem axiomatic, particularly post-9/11 as "small wars" are waged in Afghanistan and Iraq, to say that war has played a crucial role in the recent ebb and flow of globalization. As Tarak Barkawi suggests: "wars are shaped by the societies that wage them and [...] societies are shaped by the wars they wage. [...] War reacts back on its social context" $(2004,125) .{ }^{1}$ Intricately entwined in this process are cultural mediations of war: print media, television, internet, film; which reflect and impact upon the supranational networks, global power dynamics, ideologies, rivalries, and nationalisms that give rise to military conflict. As Barkawi suggests, we must

The term "small war" (limited overseas war) can be traced to C. E. Caldwell, referring to limited numbers of Europeans in combat with irregular forces in the extra-European world (Barkawi 2004, 115). The scenario created by America's most recent "small war" is aptly described by Victor David Hanson: "[Americans] have come to expect that about 150,000 professional soldiers can rout the enemy while the rest of us attend to Sex and the City and Jackass: The Movie" (qtd. in Barkawi 2004, 116). 
recognize not only that popular culture is not distinct from geopolitics, but that geopolitics is heavily inflected by the popular. War and popular culture are closely related: "citizens' subjectivities become sites of strategic significance;" the domain of the popular, then, is a "key battleground" fought over by national interests promoting military activity to achieve political objectives (Barkawi 2004, 115).

J. David Slocum, citing Michael S. Sherry, argues that militarization was "the process by which war and national security became consuming anxieties and provided the memories, models, and metaphors that shaped broad areas of national life," and concludes that, "American cinema has played an ongoing and privileged role in that process" $(2006,1)$. When we consider too the homologous relationship posited by scholars such as Paul Virilio, Jean Baudrillard and Melanie McAlister between visual media and war at many levels - technological, perceptual, ideological - we might begin to ask: on what level might these media actually serve as effective tools for resisting acts and states of war? This question is especially pertinent with regard to the United States, with many wondering whether the recent politically ambivalent or outright contentious sentiments of a number of films have any chance of undoing or even impacting upon the prevalent jingoism and nationalism of mainstream media outlets.

This essay engages with this dilemma by examining some of the contours of war representations, first characterizing historical and theoretical frameworks while considering the social and spectatorial impact of moving images that address acts of war. ${ }^{2}$ My main focus will be on what Philip Dunne rather fittingly refers to as an "idea-weapon," documentary and on a film labeled by some as antiwar propaganda: Michael Moore's Fabrenheit 9/11 (2004). Stella Bruzzi has called Moore's film "quintessential cinema documentary" (2006, 177). It exemplifies many of the self-reflexive, performative and popular elements of new documentary, veering between subversive parody of mainstream media and affective cinéma vérité. Appropriating its title from a text (Raymond Bradbury's dystopian novel Fabrenheit 451 [1953]) that interrogates forms of propaganda, Moore implies the film will engage not just with the Iraq war, but with more general problems of censorship, manipulation and truth in representation that accompany the national 'war footing.' While critical of the war and its pretexts, I would argue that the film ends up projecting ambiguous and perhaps self-contradictory conclusions about the US's reliance on war as a mechanism of global social, ideological and economic control. At the same time, it manages to capture a sense of the density, heterogeneity and instability of Americans' own national and patriotic selfperceptions.

This essay variously uses terms such as 'film,' 'motion pictures,' and 'moving images.' I am not restricting these terms to the notion of film as projected in a theater. When speaking of documentary, these terms tend to encompass a broad field, from theatrical films to televised films, DVDs, short public interest programs and news reports. Increasingly, the internet is providing wider channels for advertising, access, and distribution, but key venues still include independent movie houses, university classrooms, community centers and film festivals. 


\section{Parameters}

J.-C. Raspiengeas: Despite its deadly nature, what are your views on the new television series entitled: From the Invasion of Kuwait to the Gulf War?

Paul Virilio: It illustrates perfectly Kipling's saying: 'The first victim of war is the truth.' (Virilio 2002, 41)

To more fully consider the embedded links between motion pictures and war, it is worth examining how much of the 'old' documentarism inheres in the 'new': given that the story of film is not easily reduced to neat progressive patterns nor to clean historical/epistemological breaks; film rather tends to tell a story marked by both synchrony and diachrony, unevenness and progress. The discussion of new documentary and war, then, might start as early as the winter of 1897-98, when the fledgling US film industry was facing a financial crisis. Only two years earlier audiences had witnessed the dawning of cinema's modern age with the help of breakthroughs in camera and projection technologies - notably the Lumières' cinématographe and similar machines that followed, the popularity of which rivaled and quickly displaced the Edison Company's peep show device, the kinetoscope. By 1897, however, numerous patent lawsuits brought by Edison against his competitors were threatening to cripple the industry. At the same time, interest in the medium was beginning to wane, with audiences apparently growing weary of variety programs featuring actualities and entertainment shorts. As Charles Musser notes, even in a large city like Chicago there were no film screenings advertised during an eight-week period during the winter of 1897-1898 $(1990,226)$. What came to the rescue of the US film industry, at least in the short term, was the war film.

On 15 February 1898, an explosion on the U.S.S. Maine sent it to the bottom of Havana Harbor with two hundred and sixty-three sailors on board. The cause of the explosion was unknown, but the patriotic fervor and heightened passions that followed were soon reflected in films projected into theaters across the US. In an infamous case the Biograph Company, which a few months earlier had released a short called Battleships 'Iowa' and 'Massachusetts' (1897), re-released the same film just after the explosion, now advertised as, Battleships 'Maine' and 'Iowa.' The film was widely exhibited and found immediate success: in Chicago, "the audience arose, cheered and cheered again" (qtd. in Musser 1990, 241). As Musser argues, "much has been written about the yellow journalism and jingoistic press of Hearst and Pulitzer, but cinema complemented these efforts in a way that made them much more powerful and effective. Moving pictures projected a sense of national glory and outrage" (261). James Castonguay echoes this point while emphasizing that the Spanish-American War film should not be viewed in isolation, since it was inextricably bound to the worlds of vaudeville and journalism: that is, the emerging war film then (as now), should be viewed in the contexts of its intertextual and intermedial relations with, and interdependency upon, other popular 
media. ${ }^{3}$ Still, war films had a certain efficiency for mobilizing nationalistic spirits: rarely projected as single features, they were commonly interwoven into longer continuous programs. Amy Kaplan notes that these programs, "might start, for example, with the staged explosion of the Maine, go on to divers in the wreck, to the on-site funeral for its victims, and then move on to scenes of troops embarking for Cuba, a staged battle for the American flag, a victorious bombardment of Havana Harbor, and end with the raising of the American flag" (2002, 153). Outside, the theater would boldly advertise the program as a "War Show."

The key role that the Spanish-American War film played in helping to restore the cinema experience to mainstream popularity underlines just how central jingoistic images have been to enhancing the spectacular fascinations of the US media. A number of critics have remarked on facets of this symbiosis: notably Paul Virilio, who emphasizes how imbricated war and cinematography have been since the earlytwentieth century (especially during and after the First World War). He argues that "war is cinema and cinema is war": there is in particular a "deadly harmony" that "always establishes itself between the eye and the weapon" $(1989,26,69)$. These connections manifest themselves between scientific and aesthetic concerns in the field of optics and the demand in combat for increasingly sophisticated technologies of magnification and sighting: for ever-expanding spatial mastery and accurate targeting. The multiple meanings of the term 'to shoot,' then, might speak to a larger truth, as connoted in the name given to one of the key breakthroughs of the pre-cinematic era, Étienne-Jules Marey's chronophotographic fusil (gun/rifle), which drew its inspiration, via the inventor Jules Janssen, from the machine gun and multi-chambered Colt revolver. As Friedrich Kittler elaborates, "the transport of pictures only repeats the transport of bullets. [...] With the chronophotographic gun, mechanized death was perfected: its transmission coincided with its storage. What the machine gun annihilated the camera made immortal" $(1999,124)$. As Castonguay notes, cinematic apparatuses were "literally transformed into signifying war machines": Edison even renamed his projecting kinetoscope the "Wargraph," so closely did he identify filming with capturing and disseminating war imagery $(2006,99)$.

But Spanish-American War films also betray powerful emotional and somatic links between cinema and war that inhere alongside the scientific and aesthetic homologies enumerated so extensively by Virilio. For example, the Edison Company's Shooting Captured Insurgents (1898) is unsettling in its brutal realism: it stirs emotions and sets nerves on edge by appearing to display the cold-blooded execution of Cuban insurgents (aligned with US interests) at the hands of decorously dressed Spanish officers. Keeping in mind that one of the novelties of early

3 Castonguay asserts that there wasn't a uniformly hegemonic response to the Spanish-American War, and that there is no easy relationship one can discern between images of war and audience responses $(2006,104)$. Expanding this point, he explores records of African American audiences' discomfort at the arrival of the war and its attendant patriotic passions (Castonguay 1999).

4 For Musser, the unified subject matter and narrative coherence of Spanish-American War programs prefigured, and probably helped to initiate, the rise of narrative or 'story' films $(1990,259-61)$. 
moving images was the recreation and display of the human body in vibrant motion, this film's graphic depiction of bodies violently robbed of life - stiffly flopping to the ground after being lined against a wall and shot - perhaps carried with it an even greater visceral impact on audiences in 1898. As Karin Littau suggests, audience reactions to early cinema were in many respects registered by the body: as primarily visual media, films appealed to and touched consumers in new ways, to the point where an audience's visual pleasure might be experienced as physical sensation. Early filmgoers commonly registered physical responses to screen viewing (the classic case being the tale of screaming audiences at early screenings of Arrival of a Train at la Ciotat [1895]; Littau 2005, 43). Citing testimonials by Gorky, Yevgeni-Barkov, Méliès and others, Littau argues that film responses were registered first "involuntarily, by the body"; film viewing threatened a "forgetting of the conscious self in favour of the physical self" $(2006,50)$. Castonguay's observations concerning the widespread masculinization and militarization of existing film genres and conventions during wartime carries considerable weight in this context: "the characteristic assault on the audience exemplified by trains running toward and past the camera is replaced with soldiers on horseback charging at the spectator (as in Biograph's Roosevelt's Rough Riders)" (2006, 99).

Shooting Captured Insurgents, in its sheer simplicity and directness, can incite forms of physical shock and wordless rage at witnessing an execution. At the same time, its affective ability is in no small part facilitated by the impression that the killings at the hands of the Spanish are part of a disturbingly mundane routine. If war is - in an ongoing sense - cinema, and cinema is war, it is not only down to the technical and aesthetic innovations of cinematography and its effects, but also to the work of cinema's affect. Even early on, cinema showed that it could incite physical and emotional responses in its viewers via visual cues that gave a bodily presence to the virtual experience of war. This bodily presence is in respects enhanced when moving images are afforded documentary status, where a kind of pact between producers and consumers confirms that they are non-fictional, linked indexically to the profilmic world. Even if shorts like Battleships 'Maine' and 'Iowa' offered only visual substitutions, while Shooting Captured Insurgents fabricated and approximated the real, audiences would have been struck by the immediacy and seeming veracity of the images. Though a general concept of documentary film had not yet been formalized, these images appeared to offer direct access to their "historical referent" (Nichols 1991, 178). ${ }^{5}$ Moreover, audiences wanted them to be real.

The authority of the documentary image has long relied on its associations with factuality, a tendency that might be traced along at least one genealogical line to Enlightenment demands for more precise technologies for reporting facts and presenting evidence that might help the advance of social progress. The film

5 It is worth recalling that 'documentary' was not a recognized term for non-fiction filmmaking at this stage (the 'official' use of the term famously first appeared in 1926, in John Grierson's review of Robert Flaherty's Moana), though most audiences would have been making distinctions between factual and fictional screen images. 
documentary, in particular, continues to benefit from its widespread acceptance as a fact-based mode, an echo of Enlightenment methods of differentiating factual or "documentary" visual evidence from other more fanciful or imaginative visual representations (Smith 1992, 54). Thus documentary images, though normally drawn from the disordered realms of everyday experience, are frequently afforded pedagogical value as authoritative explanations of real phenomena and historical events. ${ }^{6}$

Documentary war films can use this authority to gesture towards or 'bring home' the outer limits of experience, combining impressions of reality with extremes of emotional and physical distress. It is this potential to combine the sensation of violent excess with the impression of quotidian experience that might be said to distinguish documentary war images from other motion picture representations of war. The immediacy conveyed by documentary images operates on audiences in quite a different fashion from, say, the vivid 'historical facsimiles' of the Civil War conjured up by David W. Griffith in The Birth of a Nation (1915) or the 'you are there' blood-spattered lens of Steven Spielberg's Saving Private Ryan (1998). ${ }^{7}$ The Edison Company's film marries visceral impact with geopolitical reality and historical facticity: enhanced by its sense of temporal simultaneity ('this could be happening somewhere now') and the illusion of the photographer's presence as witness.

If documentary images of war have been used to harness powerful public sentiments via their impressions of historical veracity and bodily immediacy (take, for example, Frank Capra's Why We Fight series), it is perhaps not surprising that many antiwar documentaries, particularly post-9/11, have tended to frame sensation within structures of logic and rational argument (as in Eugene Jarecki's response to Capra, Why We Fight [2005]). Few have played the more dangerous game, blurring the lines between rationality and sensational spectacle. A notable exception is Fabrenbeit 9/11: an "idea-weapon" which, as a result of its parodic innovations, was roundly criticized as manipulative and self-serving.

6 Michael Renov argues this conventional association of documentary with "sober discourses" misrepresents the complexity and play of the form (as in the work, for example, of Jean Vigo or Joris Ivens; Renov 2004, 100).

7 According to Stephen Prince, studies have demonstrated that documentary violence operates differently from violence in mainstream commercial cinema. Lacking the stylistic trappings of fiction films, it tends to have a different (often more profound) impact on viewers $(1999,28)$. 


\section{Shades of Ambivalence}

A war of pictures and sounds is replacing the war of objects (projectiles and missiles).

Paul Virilio $(1989,4)$

The varied nature of debates relating to links between film technology, cultural ideology and war is exemplified in the variety of approaches catalogued in J. David Slocum's collection, Hollywood and War: A Film Reader. As Slocum argues, even the word "war" is subject to refinement, given the era of continuing "small wars," insurgencies and regional conflicts: "it is necessary to recognize that 'war' is a negotiated category, indeed a kind of social institution that confers status to some organized behavior or collective conflict yet withholds it from other violent situations" $(2006,1)$. While the "small war" in Iraq clearly occupies its own specific cultural and historical locations, it is worthwhile considering its representation and mediation in the context of other wars, both 'great' and 'small,' that have occupied US national consciousness.

Writing in the wake of George Bush Senior's Gulf War of 1991, Bernd Hüppauf draws on Virilio, arguing that the glut of late 1970s and 1980s Vietnam War films reached a climax of sorts with the military and media techno-scopophilia of the Gulf War. By this point, the war film genre had "finally exhausted its critical potential” (Hüppauf 1993, 41). Citing Anton Kaes on the ever-proliferating mass reproduction of images, Hüppauf reiterates the claim that the photographic image has lost its power to persuade or to invoke historical reality. Furthermore, on the heels of the "alleged" antiwar stance of films like Full Metal Jacket (1987) and The Deer Hunter (1978), with their ambiguous moral attitudes towards conflict and their "fascination with images of modern warriors, war technology, death, killing, and mass destruction," one might observe that any binary division between the war film and the antiwar film had collapsed (Hüppauf 1993, 41). Similarly for Pierre Sorlin, the problem of producing antiwar films relates to what he calls the "stereotype" of war imagery. War images are stereotypes not because they lie, but because "they restrict the memory of war to a few recurring themes" (Sorlin 1994, 362). Though Sorlin sees these stereotypes emerging in the 1930s, they inhere in later attempts to address the follies of war, such as Stanley Kubrick's Paths of Glory (1957), Joseph Losey's King and Country (1964) or Francesco Rosi's Gli uomini contro (1970), which, though offering complex critiques of violence and conflict, also "simply repeat old images, which cannot move us deeply since we have long been accustomed to them" (Sorlin 1994, 363).

The possibility that films might be used as tools for opposing powerful war ideologies appears to recede, stacked against a growing consensus that any radical or counter-hegemonic potential in film dried up long ago. Cinema not only runs the risk of simply repeating "exhausted" images, but of further propagating patriotic and nationalist ideologies. But I am interested here in questioning, perhaps somewhat stubbornly, whether the critical potential of the antiwar film is as toothless as it 
has come to appear, and indeed whether the "final disappearance" of the binary opposition between pro and antiwar, in any event, precludes cinematic representations from intervening in or meaningfully critiquing the use of military force.

Hüppauf argues that one of the chief failings of the cinema has been the loss of a clear "moral divide" in the war genre (Hüppauf 1993, 41): this (modern) loss of a moral centre has led to a proliferation of theories collapsing war and antiwar, jingoist and pacifist. It is no longer enough to practice a humanist montage that, for example, places on the screen "increasingly brutal war conditions [...] juxtaposing them with the [suffering] human face" $(1993,63)$. Thus the strategies of Robert Capa's war photographs or films like Joris Ivens's The Spanish Earth (1937; where Ernest Hemingway's voice-over narrates images of soldiers: "this is the true face of men going into action. It is a little different from any other face you'll ever see"), suggest an "anachronistic" moral humanism that loses its impact in the context of modern warfare and the "structurally inhuman battlefield" (Hüppauf 1993, 63). Writing in the wake of the dehumanised, computerized virtual realities that typified Bush Senior's Gulf War ("surgical strikes," infrared guided missile footage, the eerie absence of human beings), Hüppauf argues that, "only mathematical space emptied of human experience but structured in abstract detail will provide the smooth sphere for the 'pure' war of technology. [...] There seems little room left for moral resistance apart from deliberately maintaining an anachronistic image of a space filled with the cries and groans and the flesh of the dying” (1993, 74-5). This posits the pointlessness of recycling antiwar strategies of the past: a film like All Quiet on the Western Front (1930) would become irrelevant (yet the film so affected its star Lew Ayres that he became a pacifist and conscientious objector in World War II, even at the expense of his career).

Finally, Hüppauf sees it as unlikely that film has any chance of producing the "powerful project of a new aesthetic" needed to confront emptied modern perception - Jean Baudrillard's "desert of the real” (Hüppauf 1993, 76). But the increasing number of films dealing with Iraq (see below) nonetheless suggests an ongoing faith in the medium's interventionist power. ${ }^{8}$ In spite of the persuasiveness of Virilio's homological conception of cinema and war and critiques regarding the exhaustion of the antiwar image, film (particularly documentary) remains a reliable and privileged medium for raising questions about war - most often via narrative content, but at times through displays of innovative form.

Putting the antiwar film in historical context, Slocum stresses that the relationship between cinema practice and the propagation of war might best be seen not as strictly pro- or antiwar, but as one of shifting shades of ambivalence. He marks the first significant phase in post-World War I films that expressed uncertainty at the suitability of US participation in the technological bloodbaths of Europe (which expressed its own pessimism in films such as The Cabinet of Dr. Caligari [1920]). The next phase can be located amidst the "glut of combat films" that

8 It is also worth reflecting on the persistent impact of metaphor. One only needs to canvass reactions to a film like Georges Franju's Le Sang de Bêtes (1949), which even now makes a powerful statement against the folly of war's mass killings. 
followed World War II, though few might be seen as adopting explicitly antiwar stances (Slocum 2006, 195). Documentary was a key site for expressing ambivalence, as in John Huston's Let There Be Light (1945), a frank treatment of combat-related post-traumatic disorders, made for the Army picture services of the US Signal Corps. But perhaps its very status as factual representation made it seem that much more dangerous as a war critique: it was banned from public view by the War Department. ${ }^{9}$

Certainly the most visible and sustained period of war scepticism in the US came during the late 1970s and 1980s, when a variety of fiction and non-fiction films dealt with US military intervention in Vietnam. This was a period that engaged with a crisis of representation itself, in particular with concerns that cinema was so deeply bound up in a global capitalist project - that the industries of war and film/media, of state and corporate power, were so vitally co-dependent - that efforts at performing antiwar critique through the production of conventional imagery or film language were futile. As David E. James cogently argues: "Consideration of the way in which even the most dissident filmmaking was incriminated, on some level or other, in the international political system of which the Vietnamese decolonization struggle was the rupture eventually produced meta-cinematic reflections that argued themselves as the only politically valid filmmaking" (James 2006, 226). James goes on to outline three prominent examples of this "politically valid" filmmaking: Émile de Antonio's In the Year of the Pig (1969), Jean-Luc Godard's segment of Chris Marker's Far From Vietnam (1967) and Nick MacDonald's The Liberal War (1972). James concludes that antiwar cinema that was radical in both content and form at best produced "a revolutionary, anti-industrial cinema that decolonized production and distribution, both participating in and enacting collective political action" $(2006,235)$.

A similar, arguably intensified, set of dilemmas faces the recent wave of cinematic critiques of war, a movement that has gained momentum since the onset of the Iraq war in 2003 and the ongoing US-led occupation. Institutionalized media outlets such as Fox News and MSNBC continue to underpin and stoke nationalist war spirit, though a series of Hollywood films featuring liberal Hollywood 'insiders' - including Jarhead (2005), The Good Shepherd (2006), Lions for Lambs (2007), Rendition (2007) and In the Valley of Elah (2007) - propounding ambivalent (if often elliptical or watered-down) stances relating to patriotism and the 'war footing' have, if not eroded, at least posed alternative views to popular support for war. ${ }^{10}$

9 The War Department's official reason for shelving the film was that the "privacy of patients [in the film] was invaded" (Pennington 1980, 1). Let There Be Light was finally released in December 1980, with an edited soundtrack that omitted the names of subjects who were still living.

10 It is unlikely these films have greatly influenced public attitudes as the occupation continues. As Sight and Sound notes, so far most of these films have been spurned by US cinemagoers (Jaafar 2008, 20). Harder-hitting films like Redacted (2007) have met with little or no box office success in the US. 
Documentary from the start offered more prolific and forthright critique, and with films like Fabrenheit 9/11 and Jarecki's Why We Fight, the antiwar film has been a growing subgenre within new documentary. Errol Morris's Fog of War (2003), an extended interview with John F. Kennedy's and Lyndon Johnson's Vietnam war czar Robert McNamara, speaks implicitly to the Iraq conflict, while others include David O. Russell's (initially suppressed) Soldiers Pay (2004) and Ellen Spiro and Phil Donohue's Body of War (2007), which foregrounds the traumatized body as the key trope for war, here following a paralysed Iraq war veteran whose ideological about-face comes on the heels of horrific physical injuries. Others have included Jehane Noujaim's Control Room (2004), Michael Tucker's Gunner Palace (2004) and Robert Greenwald's Uncovered: The War on Iraq (2003) and Iraq for Sale: The War Profiteers (2006). Recently appearing have been Nick Broomfield's staged re-enactment, Battle for Haditha (2007), Charles Ferguson's forensic analysis of haphazard preparations for war, No End in Sight (2007) and Loretta Alper and Jeremy Earp's historical study of the deceptive politics of launching wars, War Made Easy (2007, based on Norman Solomon's book). Esteban Uyarra's War Feels Like War (2004, screened on PBS) - interestingly in light of Hüppauf's comments on the exhaustion of the image of the suffering human face - eloquently employs close-ups to document the life-altering situations encountered by international journalists who refused to be 'embedded' according to the US military's demands.

It is difficult to overstate the importance of keeping abreast of these films, if the lesson of a "small war" like Vietnam offers any guidance. Film and media images, and their reception, help to track national self-perceptions. As Barkawi recalls, after the Tet offensive and the subsequent lengthy continuation of the Vietnam conflict, a widespread cultural shift took root that constituted a "direct assault on the self-perception" of many Americans: it "challenged the identity relations and ideological constructs that inspired intervention in the first place" (Barkawi 2004, 131). These ideological constructs revolved chiefly around the elite notion that "everyone, everywhere, would like to be an American, if only they had the chance" $(2004,130)$. The increasing pressure on this unifying ideology due to the Vietnam War's failures and, in no small part, to the media's increasing willingness to screen the graphic physical consequences of war, precipitated a national malaise or "cultural blowback" known as "Vietnam syndrome." But crucial to the long-term effects of Vietnam was an ideological turn that Barkawi insists is the "real" Vietnam syndrome: the ultimate rewriting of Vietnam that didn't end with 1970s social scepticism about war. Instead, popular renderings of Vietnam and its legacies began to shift, from the ambivalence of The Deer Hunter (1978) to patriotic recuperations that helped to reshape national memory (particularly in younger viewers): films such as First Blood ("Rambo," 1982), Red Dawn (1984) and We Were Soldiers (2002). These films elliptically (Red Dawn) or explicitly (We Were Soldiers) recast the Vietnam conflict as World World II-style heroism, replete with the latter's thematic and narrative trappings. Here the verdict of the Tet offensive and its aftermath (that the United States was not defending the interests of the Vietnamese), 
"is erased and America [is] reinstated as the defender of the oppressed everywhere, willing to use its military power to liberate them” (Barkawi 2004, 136).

Some have observed that US film production is in the midst of an early assessment of the Iraq war, informed by Vietnam yet well ahead of the timescale it took to widely disseminate film interpretations of that conflict. ${ }^{11}$ Of course it then needs to be asked, are there signs of an emerging 'Iraq syndrome?' If, as Barkawi argues, the successful recuperation of the Vietnam War and sublimation of the extent of Vietnamese resistance to US forces underwrote a loss of public memory, feeding into the initial widespread acceptance of the war on Iraq, then the implications for future rewritings of the current war are unsettling. Some of the crucial documentary work being done here relates to voicing those on the front lines: not just soldiers, but the Iraqi people themselves, for it is the Iraqis that have been divided, in the image of US media, into 'good' allies and 'bad' "Saddam loyalists" and "foreign terrorists." With the possible exception of a film like Sean McAllister's BBC production The Liberace of Baghdad (2004), much of this work has also had the hardest time finding adequate distribution. Of these, Steve Connors and Molly Bingham's Meeting Resistance (2007) records personal testimonials of those labeled "insurgents" by the US military and media; Usama Alshaibi's Nice Bombs (2007) documents his return, with his wife, to the turmoil of Baghdad; the film collective InCounter's About Baghdad (2004) is an account of life in Iraq just after the fall of the Ba'th regime; Melis Birder's The Tenth Planet: A Single Life in Baghdad (2004) interviews a secretary who frankly discusses her life. A series of shorts has also found limited distribution, for example David Martinez's 500 Miles to Baghdad (2007), the Al Qitaf Artistic Production Testimonials from Fallujab (2005), the anonymously made Vietnam Street (2004) and Kareem Farooq and Brian Drolet's Globalization at Gunpoint: The Economics of Occupation (2004).

Arguably, far less depends upon these films' ability to produce a "powerful project of a new aesthetic" (though several, such as Nice Bombs or Terror [2005, Termite TV Collective] are marked by innovative formal approaches) than on the seemingly insurmountable task of getting them screened to wide audiences. Here, especially with regards to distribution and visibility, the internet - with sites like YouTube, search engines that can easily locate subject-specific video material and clips on promotional websites - is playing a crucial role. But the real impact of these distribution channels is still less than clear, and the US national memory of the Iraq war is still held in the balance.

11 See for example Jaafar 2008, 16. 


\section{In the Desert of the Surreal: Fabrenbeit 9/11}

I think all this talk about [he pauses, laughs] legitimacy is way overblown.

James Baker (qtd. in Moore, Fabrenheit 9/11)

Stella Bruzzi, while avoiding laying down strict categories or implying clean breaks from the past, characterizes new documentary (since the late 1980s and 1990s) as a form inflected by increasing attention to questions of its own mediation and the prevalent problematization of the 'real.' As a consequence, new documentary tends to employ elements of performativity rather than applying solely to the task of essential truth telling. It can be seen as a "reaction against the ethos of transparency" in the wake of direct cinema's claims to unbiased observation (Bruzzi 2006, 9).

Antiwar documentary, however, might be seen as more restricted in its ability to play at the level of performativity and unstable truth claims. It opens itself to a peculiar set of problems: as inherently activist and political, it carries with it an even greater burden of expectation and demands for verifiability and accountability. It immediately enters into hotly contested fields of ideology and public opinion. But perhaps most problematic is the way it must negotiate a prevailing sensibility that information has become unreliable disinformation or 'infotainment:' that the 'real' has, paradoxically, retreated from perception with the ever increasing proliferation of 'reality' images and 'live' feeds that take precedence on our (television, internet, iPhone) screens. Finally, the antiwar film has to come to terms with the increasing tabloidization of television news and public information, and with it the perceived instability of all media 'truth.'

In the run up to the Iraq war, news broadcasts across the US rolled out colorful computer graphics, sound effects, and slogans ('Target Iraq' on NBC; 'America's New War' on CNN), offering non-stop, up-to-the-minute reports, endless screen crawls, and multiple televisual frames opening on to hyped-up (soon to be "embedded") reporters, all providing the tense, carnivalesque atmosphere now de rigeur in TV news presentation. As widely observed, the Iraq war was television's sanitized war: embedded reporting was a genius tactic assuring media collusion with US military interests, where breathless reporters could invoke World War II-style heroics while suppressing images of Iraqi dead and wounded. ${ }^{12}$ Together, these elements typify the common features of what Simon Dalby has referred to as the reductive yet dramatically successful tactics of "tabloid imperialism" (Dalby 2006, 304).

These are the networks of media oversaturation, "voluntary" censorship and postmodern disengagement that Michael Moore entered into with the making of Fabrenheit 9/11. Obviously the omnipresence of tabloid journalism and the critical/

12 Embedded reporting again recalls the Spanish-American War, where celebrity reporters like Stephen Crane and Richard Harding Davis contributed to the "correspondents war" and were even documented "assisting divers in the battleship Maine investigation" (Castonguay 2006, 98). 
ontological dilemmas it raises weighed heavily on Moore's decisions regarding how, stylistically and narratively, to approach the "war on terror" and the Iraq war. Cynthia Weber thus refers to the film as "vigilante journalism" (Weber 2006, 116). Instead of retreating to the narrative and representational certainties of more traditional approaches, Moore placed his film in dynamic dialogue with other familiar forms of information and entertainment (which would have to include his own previous, popular work): from the self-evident seriousness of PBS-style interviews to the superficiality of MTV and cheap wedding video effects: one could arguably refer to the style as a form of political and pop-cultural bricolage. ${ }^{13}$ In this sense Moore's film is exemplary of the "dialectical" tendency that Bruzzi perceives in new documentary, which reveals, "the tensions between the documentary pursuit of the most authentic mode of factual representation and the impossibility of this aim" (Bruzzi 2006, 7). But in content and style, I would suggest, it wilfully gestures beyond the dialectical production of meaning towards realms of excess and undecidability - even, as David Toohey observes, towards the formal and political tendencies of surrealism. "It is the excess of realism [i.e. 'reality'] itself," suggests Nicholas Rombes, "which creates the conditions for the revelation of absurdity that surrealism makes possible" (Rombes 2008).

Moore's film opens with fireworks etched against a night sky - an indirect reference to the "shock and awe" fire display that hit Baghdad starting on 20 March 2003 - and Moore's disembodied voice: "was it all just a dream?” After the camera pans down to Al Gore's Florida "victory" rally at the 2000 elections, Moore repeats the question: "was it a dream, or was it real?" These arguably self-reflexive lines lend, before the fact, a certain irony to the flood of accusations regarding manipulation and fakery that anticipated and followed the film's release. As Robert Brent Toplin notes, Fabrenheit 9/11 quickly became recognized "as an embarrassing example of over-the-top cinematic journalism, and Michael Moore has gained a reputation as an extremist and a propagandist" (Toplin 2005, 8). Of these critics, Christopher Hitchens was one of the most outraged, calling the film "a sinister exercise in moral frivolity, crudely disguised as an exercise in seriousness" (Hitchens 2004). But I would argue, with critics like Toohey, that Moore's politics fall somewhat closer to the tactics of the surrealist, as Fabrenbeit 9/11's initial stress on the slippage between dreams (and one assumes, nightmares) and the conscious, 'rational' world begins to suggest (Toohey 2007, 609). ${ }^{14}$

Surrealism, after the First World War, developed a powerful anti-establishment rhetoric with regards to war. André Breton's observations of shell-shocked soldiers who believed war to be a sham, staged "like some strange form of theatre," indicated ways of viewing war from alternative realities (Matheson 2006, 204; Breton 2006a,

13 See for example Dion Dennis (2005), Karen Scott (2007).

14 This view might go against the common complaint, after Fabrenheit 9/11 was awarded the Palm d'Or at Cannes, that Moore's political "reportage" did not deserve the award: that it was not "art." As Emir Kusturica argued: "It's strange to me that a jury that started its work with extensive declarations about the importance and purpose of the film industry ended up by giving the Golden Palm to reportage, the entire importance of which is that it is trying to intervene and influence the election of the next American president" (qtd. in Klein 2004). 
204). In Fabrenheit 9/11, the theme of surreal spectacle and its ambiguous relation to the real extends to the 'domestic' or 'homeland' sphere as well, where the absurd theatrics of live news coverage of election night (or in NBC's phrase, "Decision 2000") are underscored by Moore's addition of a Beverly Hillbillies-style banjo soundtrack. The surreal spectacle continues into the halls of Congress, where African American members of the House line up to decry the Supreme Court's decision to disallow an extended recount of votes in Florida. The scene ends with Maxine Waters's defiant exchange with the Chair of the proceedings, Al Gore:

AG: "Is the objection in writing and signed by a member of the House and a Senator?" MW: "The objection is in writing and I don't care that it is not signed by a member of the Senate."

AG: "The Chair will advise that the rules do care" (laughter and applause from the floor).

Waters, known for her rebellious approach to Bush Senior and "Operation Desert Storm," and as a key figure demanding justice for African Americans during the Rodney King controversy and subsequent riots/urban uprisings in Los Angeles (1992), is not an incidental presence here. ${ }^{15}$ Her then-reputation for intense political seriousness (her voice breaks with emotion in the midst of her protest) contrasts with the political circus (underscored by the laughter from the floor, which borders on ridicule) that she finds herself in. Gore's joke, too, is bounded by an ironic framework that verges on the unreal: not only is he the instrument of the very "rules" that are in fact working against his interests (and possibly those of democracy), but he appears to be making light of it. The scene offers the uncanny embodiment of Salvador Dalî's reading of martyrdom: "in order to make up for so much pain, a very intense pleasure [is] greatly called for" (Dalí 2006, 425).

As if to underscore the emptying out of truth and justice, Moore returns to the Gore celebrations in Florida, but now reverses the image, unfixing the bonds between history and the event, between representation and the 'reality' it represents. Perhaps surrealism's interest in harnessing film's oneiric "power to disorient" (Breton 2006, 786), as witnessed in the documentary experiments of Jean Vigo and Luis Buñuel, informs the approach once again. Moore's attendant voice-over: "It turns out none of this was a dream, it's what really happened," itself is rendered potentially unstable in the face of the excesses and inversions of "legitimacy" (qua James Baker's use of the term in the film, noted above) that have just come before.

When the opening credit sequence finally begins, breaking late (ten minutes) into the film, it constitutes a disruption of the spectators' absorption and a slightly jolting reminder of the process of viewing a cinematic construct, perhaps allowing viewers to reflect, albeit briefly, on the illusory power of film itself. The ensuing credit 'pre-roll' sequence then documents the image behind or edited out of the illusion: Bush administration officials preparing for the cameras. As Richard Porton notes, the images have been roundly criticized as "undignified cheap shots" (Porton 2004, 3). The sequence recalls, as Weber notes, Kevin Rafferty and James Ridgeway's

15 Waters caused controversy by referring to the Los Angeles riot/uprising as a "rebellion.” Her reputation has, since the film's release, been put under scrutiny after allegations of financial corruption. 
1992 documentary Feed, about the New Hampshire primaries (featuring thengovernor Bill Clinton), and is "not necessarily politically effective. For do we not fix ourselves up and rehearse before we go on camera?” (Weber 2006, 120). Indeed the sequence, slowed down and defamiliarized further by Jeff Gibbs's hypnotic musical score, perhaps makes a stronger aesthetic statement than a political one. The image of Paul Wolfowitz is particularly memorable. "Disgusting, and funny," Weber suggests $(2006,120)$. But also, as Wolfowitz diligently wipes his comb back and forth across his tongue before combing his hair with it, we might notice a striking resemblance to another iconic documentary figure: Nanook, performing precisely the same gesture with a bloodstained knife after eviscerating a seal. Recalling the image of Nanook, too, is Wolfowitz's broad, uninhibited smile, which exudes unexpected brightness, clarity and childlike innocence. Moore's inclusion of the shot perhaps subconsciously links his film to a wider network of unstable documentary images: here to Flaherty, the 'father' figure of American documentary, whose work has also been a flashpoint for scholarly accusations of fakery in documentary practice.

Moore's film thus appears to incorporate aesthetic and strategic elements not just of dialectical montage and self-reflexivity but of surrealism, which - as it did famously in Luis Buñuel and Dalís Un Chien andalou (1929) - drew attention to the "rape and seduction of the viewer's vision" (Conley 2005, 197). Perhaps this rape and seduction is exemplified nowhere more than in the war film (recall Shooting Captured Insurgents), with its compelling mix of nationalistic urgency and affective sensation. And it would be difficult to recall another recent "iconic" image (to use Bruzzi's term; 2006, 21) that has come closer to viewer rape and seduction than that of the endlessly repeated destruction of the Twin Towers. Once again, Moore reverses the natural order of things by refusing to privilege the field of the visual, here presenting sound without image. The technique is effective: the sound of the first plane emerging from silence and black screen impels the viewer, at the moment of impact, to imaginatively recreate the missing image. There is an infinitely brief moment, perhaps, in Eisensteinian fashion, when the viewer 'sees' the anticipated image - so deeply ingrained are the links between the sounds and the apocalyptic visions that accompany them - before recognizing its absence. As Dalí wrote, the unconscious "often confronts our consciousness with extreme cruelty;" one more reason, he argues, "to continue to reveal ourselves whenever we find friends of the truth" (Dalí 2006, 426).

The black screen image is, in practical terms, the start of the film's central narrative, which moves forward from the destruction of the towers towards the coming Iraq war and finally to its aftermath 'at home.' Moore's technique of inverting the natural order of audience expectation continues: after one minute of black screen, the image fades into the face of an African American woman (underscoring the film's prominent theme of the costs of Bush's politics and 9/11 to African Americans) gazing upwards with a shattering look of distress. Slowly, after diegetic image merges with sound, the synchronized sound begins to ebb away, replaced by music. Human figures become more marginal to the scene and the visual field 
(previously suppressed) now prevails. Finally, the film indulges in a series of (counter-intuitively) stunning aesthetic images: slow motion ashes falling like snow on Manhattan, papers blowing lazily in the wind, finally abstract images of floating debris that explicitly mirror the final shots of Michelangelo Antonioni’s Zabriskie Point (1970), itself a poetic meditation on terrorism as social disenfranchisement and confused political protest. Once again, the images recall surrealism's objectives towards "convulsive beauty" (qtd. in Flitterman-Lewis 1996, 115).

Moore's film continues to offer confidently executed but unexpected shifts in content, image, and tone (linked up primarily via his voice-over), now moving to the sequence of Bush reading The Pet Goat with schoolchildren as the towers are attacked. With this sequence, the film moves towards the more familiar comedic approach of Moore's previous work. As Paul Ward notes of the intricate relationship between comedy and factuality in recent documentary: "hybrids of comedy and the serious discourses of investigative journalism and activism [...] demonstrate that documentary need not be shackled to the notion of a 'discourse of sobriety'" (Ward 2005, 81). Comedy, too, engages with surrealism's legacy, where humor is frequently linked to anger (as in Jacques Vaché's famous quip to Breton: "Nothing kills a man so much as having to serve his country"; Vaché 2006, 213). Moore's approach carries with it too elements of both parody and satire: as Ward reminds us, parody tends to be associated with ridiculing the formal properties of a genre or individual text (in Moore's case, tabloid television news), while satire employs comedic elements to critique a wider social structure (Bush's conduct over the Iraq war).

The conservative radio host Rush Limbaugh referred to the film as a "pack of lies" (Toplin 2005, 8), and subsequent books and films (such as Alan Peterson's Fabrenhype $9 / 11$; 2004) have portrayed it as a dangerous web of deliberate misrepresentations. Yet it is interesting that far less of the parody consists of overt manipulation (such as Bush, Cheney, Rumsfeld and Blair photoshopped, with obvious sloppiness, on to the bodies of the lead actors of the TV Western Bonanza) than of the simplest technique: running US television news and found footage as it 'really' appears, recontextualizing in order defamiliarize the overly familiar. Newscasts with their 'War on Terror,' 'America on Alert,' and 'America Strikes Back' logos - brand names that explicitly transform social crisis and fear into commodity fill the screen. We see stories about the terror threats posed by poison pens and model airplanes packed with explosives, and a sequence about a high level terrorist alert for the town of Tappahannock, Virginia, played out in its 'on air' entirety with little alteration. Again, this is where Moore allows the viewer to contemplate the media world, the reflection of the 'real' world, as a surrealistic landscape of dreams and nightmares. ${ }^{16}$

16 The media scenario is reminiscent of the state of paranoia as figured by Dalí (glossing Freud): "The paranoiac who believes himself to be poisoned discovers in everything that surrounds him, right up to the most imperceptible and subtle details, preparations for his own death" (Dalí 2006, 426). 
But even with its complex bricolage and auteurist displays of directorial and editing virtuosity, Moore's film ultimately demands partial recuperation of its own subversive potential. This is no more evident than in Moore's self-projection as the prototypical American everyman, or "Little Man" in baseball cap, t-shirt, and baggy jeans, as observed by numerous critics (for example Rizzo 2005/06, 32-4; Nolley 2005, 13; Weber 2006, 124-5). Moore tends to place himself prominently, like a supersized version of Chaplin's Little Tramp, at the center of the narrative and often at the center of the screen frame itself. For example, while the facts of Bush's tarnished military record and intimate relations with James R. Bath, who worked in a financial capacity for the bin Ladens, should not fail to convince (and are underwritten by Craig Unger's House of Bush, House of Saud, 2004), the overstated manner in which Moore introduces them threatens their validity. The sequence opens with a heroic, slow motion shot of Moore himself in profile, framed by an American flag and a captivated audience; soothing piano emotionalizes the scene. Moore's voice-over stresses his popular influence: "I called George W. Bush a deserter $[\ldots]$ in response, the White House released his military records." The theme of cat and mouse enacted in Roger and Me (1989) and subsequent Moore films returns here with force, leaving this scene's specific political implications subsumed to little man/big man personality clashes enacted elsewhere. While the scenes reconstructing the Bush/Bath case are intriguingly imaged through interwoven images of appearing and disappearing textual evidence accompanied by a pulsating score reminiscent of The Thin Blue Line (1988), one striking difference from the latter film is, once again, Moore's authoritative interpretation of the image via the use of his own voice-over. Once again this positions Moore as the figure of authority and audience identification, a "US 'we' that [...] is hyper-individualized and utterly collectivized at the same time" (Weber 2006, 124). But as Weber further notes, Moore generally fails "to mouth the extremely complex and varied moral objections many Americans have to the Bush administration's security policies," and rather poses "his own morally certain opposition to the moral certainty of the Bush administration" (2006, 129). This tendency towards an oppositional framework: 'good' Moore/us versus 'bad' Bush/them, undercuts the film's potential to construct complex truths and produce potentially transformational, counterhegemonic arguments.

Finally there is Lila Lipscomb, who, for all the power of her emotive screen presence, is interestingly positioned within Moore's diegesis not to critique patriotism and nationalism in favor of pacifism, but to reassert more traditional senses of national identity amidst an increasingly deceptive post-9/11 political climate. A typical example of this appears when interviewing Lila in her kitchen: "It's a great country," Moore utters in almost perfunctory fashion, and she quickly agrees. Lila appears as nothing less than the patriotic everywoman, though she is disillusioned with this war. We are led to believe that she would not be mourning her loss in quite the same way had she thought the sacrifice were 'justified.' In interviews, Lipscomb's argument echoes Moore's, framing the key issue not as an interrogation of the moral rightness of war but as one of "lies" uttered by politicians: "my son 
got sent into harm's way by a decision made by the President of the United States that was based on a lie" (Brockes 2004). Here the message of Fabrenheit 9/11 diverges widely from surrealism, which powerfully "eschewed any willingness to die for one's country" (Toohey 2007, 612). The blame, rather, is squarely placed on the President.

This is reflected in Lila's most affective scene, breaking down in front of a barricaded White House (another instance of convention turned on its head: here the symbol of American democracy signifies an inward-looking, uncaring, and self-protective administration). Though Lila's grief is palpable and convincing, in these scenes, Weber rightly suggests that the shift away from Moore's preeminent presence to Lila's in many ways signals his appropriation of Lila's sympathetic yet authoritative feminine voice as his own (Weber 2006, 128). The shift in focus from director to subject here is signaled by a stylistic shift from parody and surreal montage towards the techniques of direct cinema. Though it is difficult to imagine another approach that could have done justice to Lila's narrative, direct cinema (drawn from cinéma vérité) carries with it its own conventional presumptions of a lack of mediation, of "[film] material as evidence" (Winston 1988, 26). At the same time, the direct cinema technique has become roundly critiqued for its frequently crass manipulation of these very presumptions (as in 'reality' TV).

Even with the weight of cinéma vérité-style immediacy behind her, Lila's function as a character in Moore's film is ultimately reminiscent of traditional representations of mothers in war films, who often are figured as, "emotional and sentimental counterweights to an unwelcome task that had to be done [the sacrifice of the child] rather than vigorous proponents of peace at any price" (Isenberg 1981, 196). Lila's figure thus recalls the patriotic war mother in films of the 1930s and 1940s who, Isenberg suggests, for all their collective grieving, almost always stopped short of declarations of pacifism. On the other hand, it could also be argued that something uncanny in Lila's figure lingers beyond the frame, perhaps even beyond Moore's framing of her. Her grief marks the pronounced gap between the ideal and the reality of war: those accepting the hypothetical loss of a child in military conflict - justified or otherwise - can radically change in the face of actual loss.

\section{Conclusion}

As Weber argues of Fabrenheit 9/11, there appears to be no utopian vision, "just a warning about our current and possibly future dystopia" (Weber 2006, 118). The same might be said of a number of recent antiwar films, such as Jarecki's Why We Fight, which conveys a multi-layered, densely historical argument about the Iraq war as an inevitable outcome of the growth of the military industrial complex. Employing a straightforward visual essay approach, Why We Fight combines archival footage with interviews and interviewees' voice-overs, compiling evidence to contest the insistence of Bush administration officials that the US faces an unprecedented "new war" on terror, for which there is no relevant history or 
precedent. ${ }^{17}$ Yet, as in Moore's film, the critique of the military industry stops well short of pacifist or anti-nationalist pronouncements, sidestepping (as it turned out, unsuccessfully for Moore) accusations of anti- or un-Americanism.

A widely distributed publicity shot for Boweling for Columbine (2002) shows Moore with two objects, one slung over each shoulder: a gun and a camera. This explicit connection not only underlines the film's subject matter, but suggests a project behind it: to use the camera to combat what Moore views as the ingrained beliefs and corporate deceptions that support the US gun trade. But as in Fabrenheit $9 / 11$, the film ultimately reduces denser questions of cultural and psychic investment in violence to the realm of little people enacting victories against corporate interests (in Bowling for Columbine, this extends to the successful lobbying for the suspension of ammunition sales in Kmart). Similarly, many recent antiwar films avoid examining embedded, mythic structures of conquest and imperial 'right' that have underwritten support of the use military force in carrying out US foreign policy objectives. Even fewer strive towards taking up H.H. Carr's complex challenge of affecting "peaceful change," avoiding recourse to war, in the realm of international politics (qtd. in Miall 2007, 5). This might suggest that, even in the wake of Abu Ghraib and other emerging images of suffering and abuse, any 'Iraq syndrome' in the making is still quite some distance from the radical refashioning of American self-perceptions that took place, albeit briefly, in the wake of Vietnam.

\section{Works Cited}

Barkawi, Tarak (2004). "Globalization, Culture, and War: On the Popular Mediation of 'Small Wars." Cultural Critique 58 (Fall), 115-47.

Barsam, Richard Meran (1974). Nonfiction Film: A Critical History. London: George Allen and Unwin.

Breton, André (2006a [1918]). "Subject." Neil Matheson, ed. The Sources of Surrealism. Aldershot: Ashgate, 204-5.

— (2006 [1951]). "As in a Wood." Neil Matheson, ed. The Sources of Surrealism. Aldershot: Ashgate, 786-92.

Brockes, Emma (2004). "The lie that killed my son." The Guardian. July 8. $<$ http:/film.guardian.co.uk/interview/interviewpages/0,,1256559,00.html> (February 1, 2008).

Bruzzi, Stella (2006). New Documentary. New York: Routledge.

Castonguay, James (1999). "The Spanish-American War in U.S. Media Culture." American Quarterly <http://chnm.gmu.edu/aq/war/> (January 15, 2008).

- (2006). "The Spanish-American War in United States Media Culture.” J. David Slocum, ed. Hollywood and War: The Film Reader. London: Routledge, 97-108.

17 See Melani McAlister's assessment of the Bush administration's ahistoricism (McAlister 2002, 455). 
Conley, Tom (2005). “Un Chien andalou: A Rape of the Eye.” Jeffrey Geiger and R. L. Rutsky, eds. Film Analysis: A Norton Reader. New York: W.W. Norton, 196-215.

Dalby, Simon (2006). “The Pentagon’s New Imperial Cartography: Tabloid Realism and the War on Terror.” Derek Gregory and Allan Pred, eds. Violent Geographies: Fear, Terror, and Political Violence. New York: Routledge, 295-308.

Dalí, Salvador (2006 [1930]). “The Moral Position of Surrealism.” Neil Matheson, ed. The Sources of Surrealism. Aldershot: Ashgate, 424-7.

Dennis, Dion (2005). "Public Intellectuals, Information Politics, and the Manichean Moment.” Fast Capitalism 1.2. < http://www.uta.edu/huma/agger/fast capitalism/1_2/dennis.html > (February 1, 2008).

Fabrenbeit 9/11 (2004). Dir. Michael Moore. Lions Gate Films.

Flitterman-Lewis, Sandy (1996). "The Image and the Spark: Dulac and Artaud Reviewed." Rudolf E. Kuenzli, ed. Dada and Surrealist Film. Cambridge, MA: MIT Press, 110-27.

Hitchens, Christopher (2004). "Unfairenheit 9/11: The Lies of Michael Moore." Slate. June 21. <http://www.slate.com/id/2102723/> (January 15, 2008).

Hüppauf, Bernd (1993). "Experiences of Modern Warfare and the Crisis of Representation.” New German Critique 59, 41-76.

Isenberg, Michael (1981). War on Film: The American Cinema and World War I, 1914-1941. Madison, NJ: Fairleigh Dickinson University Press.

Jaafar, Ali (2008). "Casualties of War.” Sight and Sound 18.2, 16-22.

James, David E. (2006). "Film and War: Representing Vietnam.” J. David Slocum, ed. Hollywood and War: The Film Reader. London: Routledge, 225-38.

Kaplan, Amy (2002). The Anarchy of Empire in the Making of U.S. Culture. Cambridge, MA: Harvard University Press.

Kittler, Friedrich D. (1999). Gramophone, Film, Typewriter. Trans. Geoffrey Winthrop-Young and Michael Wutz. Stanford, CA: Stanford University Press.

Klein, Uri (2004). "Director Emir Kusturica: Human Cinema Will Survive." Haaretz.com. July 13. <http://www.mfa.gov.yu/FDP/haaretz_130704_e.html> (February 1, 2008).

Littau, Karin (2005). "Arrival of a Train at La Ciotat: Silent Films and Screaming Audiences.” Jeffrey Geiger and R. L. Rutsky, eds. Film Analysis: A Norton Reader. New York: W.W. Norton, 42-62.

- (2006). Theories of Reading: Books, Bodies, and Bibliomania. London: Polity.

Matheson, Neil, ed. (2006). The Sources of Surrealism. Aldershot: Ashgate.

McAlister, Melani (2001). Epic Encounters: Culture, Media, and U.S. Interests in the Middle East, 1945-2000. Berkeley, CA: University of California Press.

- (2002). "A Cultural History of War Without End.” Journal of American History 89.2, 439-55.

Miall, Hugh (2007). Emergent Conflict and Peaceful Change. Basingstoke: Palgrave Macmillan.

Musser, Charles (1990). The Emergence of Cinema: The American Screen to 1907. Berkeley, CA: University of California Press. 
Nichols, Bill (1991). Representing Reality: Issues and Concepts in Documentary. Bloomington, IN: Indiana University Press.

Nolley, Ken (2005). "Fabrenheit 9/11: Documentary, Truth-Telling, and Politics." Film and History 35.2, 12-6.

Pennington, Ron (1980). "Huston's 'Light' Cleared for Limited Screening After 35 Years." Hollywood Reporter. December 16, 1 and 4.

Porton, Richard (2004). "Weapons of Mass Instruction: Michael Moore's Fabrenbeit 9/11." Cineaste 29.4, 3-8.

Prince, Stephen (1999). "Graphic Violence in Cinema: Origins, Aesthetic Design, and Social Effects.” Stephen Prince, ed. Screening Violence. New Brunswick, NJ: Rutgers University Press, 1-44.

Renov, Michael (2004). The Subject of Documentary. Minneapolis, MN: University of Minnesota Press.

Rizzo, Sergio (2005/06). "Why Less is Still Moore: Celebrity and the Reactive Politics of Fabrenbeit 9/11." Film Quarterly 59.2, 32-9.

Rombes, Nicholas (2008). "Too Much Reality: Tracing New Wave Surrealism's Roots." Solpix: Film and Fiction. <http://www.webdelsol.com/SolPix/spnicksurrel.htm $>$ (January 15, 2008).

Scott, Karen (2007). “Bowling for Columbine: Postmodern Cinéma Vérité?” In the Picture: The Media Education Magazine. <http://www.itpmag.demon. co.uk/ Downloads/ columbine.html> (February 15, 2008).

Slocum, J. David, ed. (2006). Hollywood and War: The Film Reader. London: Routledge.

Smith, Bernard (1992). Imagining the Pacific. New Haven, CT: Yale University Press.

Sorlin, Pierre (1994). "War and Cinema: Interpreting a Relationship." Historical Journal of Film, Radio, and Television 14.4, 357-66.

Toohey, David (2007). "Material Objects and Aura: Popular Images Against and For War.” Review of Policy Research 24.6, 609-26.

Toplin, Robert Brent (2005). "The Long Battle Over Fabrenbeit 9/11: A Matter of Politics, Not Aesthetics." Film and History 35.2, 8-10.

Vaché, Jacques (2006 [1919]). "From War Letters." Neil Matheson, ed. The Sources of Surrealism. Aldershot: Ashgate, 212-4.

Virilio, Paul (1989). War and Cinema: The Logistics of Perception. Trans. Patrick Camiller. New York: Verso.

- (2002). Desert Screens: War at the Speed of Light. Trans. Michael Degener. London: Athlone Press.

Ward, Paul (2005). Documentary: The Margins of Reality. London: Wallflower.

Weber, Cynthia (2006). "Fabrenbeit 9/11: The Temperature Where Morality Burns." Journal of American Studies 40.1, 113-31.

Winston, Brian (1988). "Documentary: I Think We Are in Trouble." Alan Rosenthal, ed. New Challenges for Documentary. Berkeley, CA: University of California Press.

Why We Fight (2005). Dir. Eugene Jarecki. BBC Storyville. 